\title{
Analysis of daily body weight of dairy cows in early lactation and associations with productive and reproductive performance
}

\author{
Jessica Karina Poncheki ${ }^{1}$, Maria Luíza Schultz Canha ${ }^{2}$, Sandro Luiz Viechnieski ${ }^{3}$, \\ Rodrigo de Almeida ${ }^{4}$
}

\author{
1 Universidade Federal do Paraná, Programa de Pós-graduação em Ciências Veterinárias, Curitiba, PR, Brasil. \\ 2 Universidade Federal do Paraná, Curitiba, PR, Brasil. \\ ${ }^{3}$ Fazenda Star Milk, Céu Azul, PR, Brasil. \\ ${ }^{4}$ Universidade Federal do Paraná, Departamento de Zootecnia, Curitiba, PR, Brasil.
}

\begin{abstract}
The objective of this study was to describe daily body weight (BW) changes in the first 100 days of lactation in confined dairy cows and to associate BW loss with productive and reproductive performance. Data included 26,344 daily BW measurements of 372 Holsteins calving between June 2011 and June 2012 in a commercial herd in the South of Brazil. Cows were automatically weighed and were assigned according to parity. Individual measurements were smoothed using cubic splines, generating nadir BW, days to nadir BW and the BW loss (absolute and relative values). This approach used days in milk (DIM) as a single smoothing variable. Body weight at calving differed across parities: $570.5,653.5$, and $699.9 \mathrm{~kg}$, for the 1st, 2nd and 3rd and subsequent parities, respectively. Body weight at nadir also differed across parities: $521.5,608.8$, and $647.3 \mathrm{~kg}$, respectively. Mean days from calving BW to nadir BW and mean loss of BW (kg) from calving to nadir BW did not differ across parities, but relative BW change $(\mathrm{kg} / 100 \mathrm{~kg})$ was larger in animals in first parity $(-8.4 \mathrm{~kg} / 100 \mathrm{~kg})$ than second parity $(-6.6 \mathrm{~kg} / 100 \mathrm{~kg})$. However, cows in first parity had more chances for good reproduction than cows in third and subsequent parities (44.0\% vs. $30.7 \%$, respectively). There was no difference in the probability of adequate reproduction (pregnant until 180 DIM) among cows with low, medium, or high milk yield. Furthermore, cows with low and medium BW loss (below $60 \mathrm{~kg}$ of BW change) showed more likelihood to adequate reproduction than cows with high BW loss (above $60 \mathrm{~kg}$ of BW): 45.5 and $45.8 \%$ vs. $24.4 \%$, respectively. Improvements in fertility of dairy cows should be achieved by minimizing body weight loss in early lactation.
\end{abstract}

Key Words: body weight loss, milk production, pregnancy ratio, transition period

\section{Introduction}

The transition period (three weeks before to three weeks after calving) has been considered the stage of highest interest in the life of dairy cows (Drackley, 1999). Over this period, animals undergo several anatomical, physiological, hormonal, and metabolic changes. Because of these, this is the period of most concern in terms of nutrition and occurrence of metabolic and infectious disorders (Dubuc et al., 2010).

In the past few decades, advancements in general management, nutrition, health, and animal breeding have yielded significant increases in productivity of cows. But some authors have associated increases in milk yield with decreases in pregnancy ratio (Santolaria et al., 2012). Roche (2006) stated that high-producing cows have a greater negative energy balance (NEB) and its magnitude

Received December 9, 2014 and accepted March 29, 2015.

Corresponding author: ralmeida@ufpr.br

http://dx.doi.org/10.1590/S1806-92902015000500004

Copyright (@) 2015 Sociedade Brasileira de Zootecnia. This is an Open Access article distributed under the terms of the Creative Commons Attribution Non-Commercial License, which permits unrestricted non-commercial use, distribution, and reproduction in any medium, provided the original work is properly cited. is directly related to reproductive failure. Considering the calving interval should be 13-14 months ideally, cows should be pregnant up to 120-150 days after calving, and those that do not meet this target are at higher chance of being culled (Alawneh et al., 2012).

The return of ovarian activity after calving is closely related to the NEB, common in early lactation. This is due to low intake capacity, which makes the energy input lower than the demands for production and maintenance (NRC, 2001). Therefore, cows end up using their body reserves to meet the energy requirements for lactation (Choumei et al., 2006).

Since most cows undergo a period of NEB and later they recover from this physiological state, some authors such as Jorritsma et al. (2003) suggested the term "adaptation to NEB". The dairy industry had traditionally adopted body condition score (BCS) to evaluate BW loss in early lactation (Wildman et al., 1982). But, more recently, Drackley et al. (2014) demonstrated that BCS may lack sensitivity to detect differences in visceral fat deposition that might increase risk for peripartal diseases and disorders.

One way to identify the individual level of adaptation of fresh cows to NEB is to measure their body weight variation, since cows with excessive mobilization of body 
reserves are at higher risk for metabolic disorders (Bobe et al., 2004), have poorer reproductive performance (Santos et al., 2009), and produce smaller yields of milk (Reist et al., 2003).

The purpose of this study was to describe and quantify daily body weight (BW) changes in the first 100 days of lactation in dairy cows and correlate them with productive and reproductive performance.

\section{Material and Methods}

The study was conducted on a commercial dairy farm located in the city of Céu Azul, southwest region of Paraná

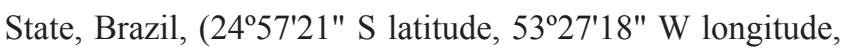
and $785 \mathrm{~m}$ altitude). The region has humid subtropical climate (Cfa, according to the Köppen-Geiger classification). Lactating Holstein cows were kept confined in free stall barns and milked three times daily.

They were fed a total mixed ration five times daily, and the diet was formulated (Table 1) in agreement with the nutritional guidelines of NRC (2001). The estimated nutritional levels of this diet using the NRC (2001)'s software are $565 \mathrm{~g} \mathrm{~kg}^{-1}$ dry matter, $1.75 \mathrm{Mcal} \mathrm{kg} \mathrm{k}^{-1}$ net energy for lactation, $175 \mathrm{~g} \mathrm{~kg}^{-1}$ crude protein, $54 \mathrm{~g} \mathrm{~kg}^{-1}$ undegradable protein, $325 \mathrm{~g} \mathrm{~kg}^{-1}$ neutral detergent fiber, $190 \mathrm{~g} \mathrm{~kg}^{-1}$ acid detergent fiber, $196 \mathrm{~g} \mathrm{~kg}^{-1}$ physically effective neutral detergent fiber, $385 \mathrm{~g} \mathrm{~kg}^{-1}$ non-fibrous carbohydrates, $270 \mathrm{~g} \mathrm{~kg}^{-1}$ starch, $46 \mathrm{~g} \mathrm{~kg}^{-1}$ ether extract, $9.1 \mathrm{~g} \mathrm{~kg}^{-1} \mathrm{Ca}$, and $4.1 \mathrm{~g} \mathrm{~kg}^{-1} \mathrm{P}$.

The present study used 26,344 daily BW measurements from 372 Holstein cows collected between June 02, 2011 and July 1st, 2012. The average number of weight records was lower than 100 (approximately 71 daily weights per cow), because sick cows on treatment were kept in a different barn and missed the weight collection on these days.

Body weight data started to be collected just after calving, and they were obtained after the second daily milking, always at the exit of the milking parlor, using an

Table 1 - Ingredient composition of the diet during the experimental period

\begin{tabular}{lc}
\hline Ingredients & $\mathrm{g} \mathrm{kg}^{-1}$ of DM \\
\hline Corn silage $\left(320 \mathrm{~g} \mathrm{~kg}^{-1} \mathrm{DM}\right)$ & 324.1 \\
Alfalfa hay $\left(880 \mathrm{~g} \mathrm{~kg}^{-1} \mathrm{DM}\right)$ & 69.2 \\
Corn grain, ground & 235.4 \\
Soybean meal & 168.9 \\
Soybean hulls & 75.8 \\
Whole cottonseed & 91.3 \\
Calcium salts of soybean oil & 7.1 \\
Mineral-vitamin mix ${ }^{1}$ & 28.2 \\
\hline Contained (g kg-1 DM basis): Ca - 166.3; P - 30.8; K - 2; S - 18; Na - $100.8 ; \mathrm{Cl}-30.3$; \\
Mg - 57.4; I - 29.76 ppm; Se - 14.85 ppm; Mn - 646.35 ppm; Zn - 2,545.55 ppm; \\
Cu - 511.44 ppm; Co - 5.0 ppm; vit. A - 176,800 IU; vit. D - 53,240 IU; vit. E - 75.17 IU; \\
monensin - 390 mg; biotin - 31.68 mg.
\end{tabular}

automated walk-through scale for the measurement of daily BW (Automatic Weighing System AWS 100, DeLaval ${ }^{\circledR}$, Jaguariúna, Brazil) according to their identification. These data, along with management, production, and reproduction data, were recorded using the $\mathrm{ALPRO}^{\circledR}$ management software. Lactating animals were categorized into three groups according to their parity order: first parity $(\mathrm{n}=152)$, with calving age of $27.2 \pm 3.8$ months; second parity $(\mathrm{n}=100)$, with calving age of $41.9 \pm 6.2$ months; and third and subsequent parities $(n=120)$, with $71.0 \pm 19.3$ months of age.

The production variable assessed herein considered the cumulative milk production over the first 100 days in milk (DIM). To evaluate the reproductive performance, cows were considered reproductively successful when pregnant within 180 DIM and unsuccessful when not pregnant within the same period or diagnosed as pregnant after 180 DIM.

For generating variables representing $\mathrm{BW}$ changes in early lactation and further analysis of the BW data, individual measurements were first smoothed using cubic splines from the TPSLINE procedure of the SAS (Statistical Analysis System, version 9) statistical package. This procedure minimized any possible random weight deviations. The model contained the time DIM unit as a single smoothing variable. Five variables were estimated to reflect BW changes: BW at calving; BW at nadir; days from calving to nadir BW; BW (kg) lost from calving to nadir; and relative $\mathrm{BW}\left(\mathrm{kg} 100 \mathrm{~kg}^{-1}\right)$ change from calving to nadir. The average BW in the first 100 DIM was categorized according to parity order and smoothed using cubic splines from the TPSLINE procedure from SAS.

Descriptive statistical analysis and Pearson partial correlation coefficients adjusted for parity order were estimated by the CORR procedure from SAS (Statistical Analysis System, version 9). Significance of the parity order was determined using the $F$-test for the type-III sum of squares (GLM procedure from SAS, Statistical Analysis System, version 9). Statistical significance was declared to be significant at $\mathrm{P} \leq 0.05$. Tukey-Kramer tests were conducted to analyze differences among groups.

Data was analyzed by a multivariate logistic regression using the GENMOD procedure from SAS (Statistical Analysis System, version 9), to determine the likelihood of adequate reproduction, assuming binomial distribution (failure or success to achieve pregnancy at 180 DIM). For analysis of whether pregnancy had occurred by 180 days postpartum, the model included parity (first, second, and third and subsequent parities), calving season (summer, fall, winter, and spring), cumulative milk yield in the first 100 days postpartum categorized within parity (primiparous and multiparous), and BW change from calving to nadir BW 
categorized. Adjusted odds ratio (AOR) and 0.95 confidence interval $(\mathrm{CI})$ were generated during the logistic regression.

Cumulative milk yield in the first 100 days postpartum was categorized into low, medium, and high production according to the parity order. For primiparous cows, cumulative milk yield in the first 100 DIM lower than $3,000 \mathrm{~kg}$ was considered "low production"; between 3,000 and $3,700 \mathrm{~kg}$, "medium production"; and above $3,700 \mathrm{~kg}$, it was classified as "high production". For multiparous cows, cumulative milk yield in the first 100 DIM lower than $3,300 \mathrm{~kg}$ was considered "low production"; between 3,300 and 4,100 kg, "medium production"; and above 4,100 kg, it was classified as "high production".

Body weight loss from calving to nadir BW was categorized into three classes: low BW loss (lower than $30 \mathrm{~kg}$ ), medium BW loss (between $30 \mathrm{~kg}$ and $60 \mathrm{~kg}$ ), and high BW loss (greater than $60 \mathrm{~kg}$ ). The same criteria were adopted across parities because GLM results showed no BW change differences (in absolute values) among parities.

\section{Results}

The mean BW at calving for the 372 cows was $637 \pm 91 \mathrm{~kg}$ and nadir BW was $586 \pm 85 \mathrm{~kg}$, a variation of $51 \mathrm{~kg}$. Cumulative yields over the first 100 DIM were $3,410 \mathrm{~kg}$ for first parity, $3,862 \mathrm{~kg}$ for second parity, and $3,775 \mathrm{~kg}$ for third and subsequent parities (Table 2).

The BW at calving were $570.5 \mathrm{~kg}, 653.5 \mathrm{~kg}$, and $699.9 \mathrm{~kg}$, for first, second and third and subsequent parities, respectively. As for nadir BW, the same trend of the BW at calving was observed, with first-parity cows at $521.5 \mathrm{~kg}$, second-parity cows at $608.8 \mathrm{~kg}$, and cows in their third and subsequent parities at $647.3 \mathrm{~kg}$.

The number of days from BW at calving to nadir BW was 35.7, 32.9, and $37.8 \mathrm{~d}$ for first, second, and third and subsequent parities, respectively, and the absolute weight loss was 48.9, 44.7, and $52.6 \mathrm{~kg}$ for first, second, and third and subsequent parities, respectively. Weight variation in relative values for first-parity animals was $-8.4 \mathrm{~kg} / 100 \mathrm{~kg} \mathrm{BW}$, $-6.6 \mathrm{~kg} / 100 \mathrm{~kg}$ for second-parity cows, and cows in their third and subsequent parities had $-7.3 \mathrm{~kg} / 100 \mathrm{~kg} \mathrm{BW}$.

The cumulative milk yield had positive correlations with calving $\mathrm{BW}$, nadir $\mathrm{BW}$, days to nadir $\mathrm{BW}$, and loss to nadir BW (0.24, 0.20, 0.17, and 0.11, respectively) (Table 3$)$. Calving BW had positive correlations with nadir BW, days to nadir $\mathrm{BW}$, and loss to nadir $\mathrm{BW}(0.86,0.28$ and 0.43 , respectively), and a negative correlation with relative $\mathrm{BW}$ change (-0.29). First-parity animals had $44.0 \%$ of chance of a satisfactory reproduction; second-parity order, $39.6 \%$; and cows with three or more parities had $30.7 \%$ (Table 4). In the present study, animals that had calved in the fall had $54.2 \%$ chances of adequate reproduction; summer-calved, $32.9 \%$, winter-calved, $28.6 \%$; and spring-calved animals showed $37.6 \%$ chances of adequate reproduction.

The likelihood of adequate reproduction among low (below $60 \mathrm{~kg}$ of BW change), medium (between $30 \mathrm{~kg}$ and $60 \mathrm{~kg}$ of BW) and high (above $60 \mathrm{~kg}$ of BW) cumulative milk yields were 45.5 and $45.8 \%$ vs. $24.4 \%$, respectively. Body weight decreases after calving until reaching the nadir $\mathrm{BW}$, and this occurs similarly to all parity classes (Figure 1).

Table 2 - Cumulative milk yield in the first 100 days in milk, body weight (BW) at calving, nadir BW, days to nadir BW, and difference between BW at calving and nadir BW in absolute and relative values, according to parity order

\begin{tabular}{|c|c|c|c|c|c|c|}
\hline \multirow[b]{3}{*}{ Variable } & \multicolumn{6}{|c|}{ Parity order } \\
\hline & \multicolumn{2}{|c|}{ 1st parity } & \multicolumn{2}{|c|}{ 2nd parity } & \multicolumn{2}{|c|}{ 3rd+ parity } \\
\hline & Mean & $\mathrm{SE}$ & Mean & $\mathrm{SE}$ & Mean & SE \\
\hline Cumulative yield (kg) & $3365 b$ & 64.0 & $3791 \mathrm{a}$ & 80.7 & $3705 a$ & 75.5 \\
\hline Calving BW $(\mathrm{kg})$ & $570.5 c$ & 5.9 & $653.5 b$ & 7.4 & $699.9 \mathrm{a}$ & 6.8 \\
\hline Nadir BW (kg) & $521.5 \mathrm{c}$ & 5.3 & $608.8 b$ & 6.7 & $647.3 \mathrm{a}$ & 6.2 \\
\hline Days to nadir BW & $35.7 \mathrm{a}$ & 1.9 & $32.9 \mathrm{a}$ & 2.4 & $37.8 \mathrm{a}$ & 2.2 \\
\hline BW loss to nadir (kg) & $48.9 \mathrm{a}$ & 2.9 & $44.7 \mathrm{a}$ & 3.7 & $52.6 \mathrm{a}$ & 3.4 \\
\hline BW change to nadir $(\mathrm{kg} / 100 \mathrm{~kg} \mathrm{BW})$ & $-8.4 \mathrm{a}$ & 0.4 & $-6.6 b$ & 0.5 & $-7.3 \mathrm{ab}$ & 0.5 \\
\hline
\end{tabular}

abc - values followed by different letters within the same row differ at $\mathrm{P}<0.05$.

SE - standard error.

Table 3 - Pearson partial correlation coefficients adjusted for parity order

\begin{tabular}{|c|c|c|c|c|c|}
\hline & Calving BW (kg) & Nadir BW (kg) & Days to nadir & Loss to nadir (kg) & $\begin{array}{l}\text { Relative change to nadir } \\
(\mathrm{kg} / 100 \mathrm{~kg} \mathrm{BW})\end{array}$ \\
\hline Cumulative yield (kg) & $0.24(<0.01)$ & $0.20(<0.01)$ & $0.17(<0.01)$ & $0.11(<0.05)$ & $-0.07(\mathrm{NS})$ \\
\hline Calving BW (kg) & & $0.86(<0.01)$ & $0.28(<0.01)$ & $0.43(<0.01)$ & $-0.29(<0.01)$ \\
\hline Nadir BW (kg) & & & $0.09(\mathrm{NS})$ & $-0.09(\mathrm{NS})$ & $0.23(<0.01)$ \\
\hline Days to nadir & & & & $0.38(<0.01)$ & $-0.36(<0.01)$ \\
\hline Loss $(\mathrm{kg})$ to nadir & & & & & $-0.98(<0.01)$ \\
\hline
\end{tabular}


Table 4 - Risk factors for adequate reproduction at 180 days in milk for lactating dairy cows

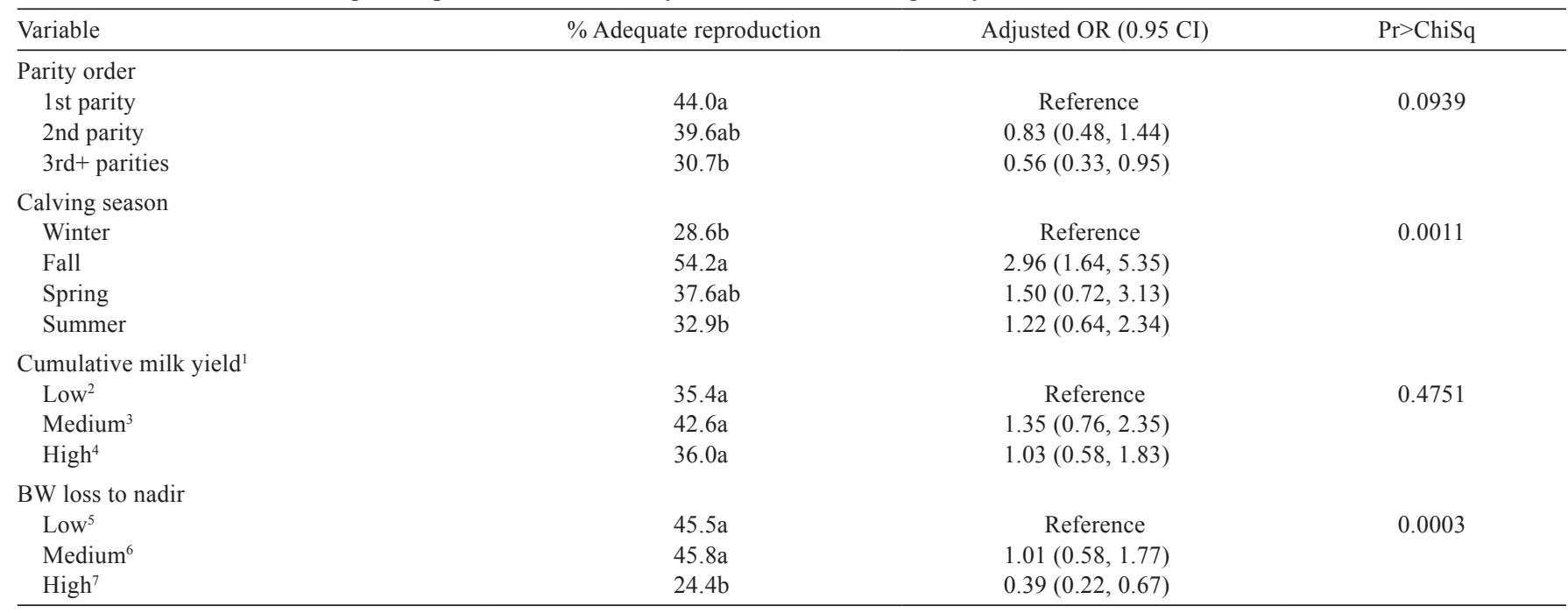

OR - odds ratio; CI - calving interval; $\mathrm{Pr}>\mathrm{ChiSq}$ - associated P-value.

${ }^{1}$ Cumulative milk yield until 100 days in milk.

${ }^{2}$ First parity $<3,000 \mathrm{~kg}$; second parity and greater $<3,300 \mathrm{~kg}$.

${ }^{3}$ First parity $\geq 3,000 \mathrm{~kg}$ and $\leq 3,700 \mathrm{~kg}$; second parity and greater $\geq 3,300 \mathrm{~kg}$ and $\leq 4,100 \mathrm{~kg}$.

${ }^{4}$ First parity $>3,700 \mathrm{~kg}$; second parity and greater $>4,100 \mathrm{~kg}$.

${ }^{5}$ Body weight loss $<30 \mathrm{~kg}$.

${ }^{6}$ Body weight loss $\geq 30 \mathrm{~kg}$ and $\leq 60 \mathrm{~kg}$.

${ }^{7}$ Body weight loss $>60 \mathrm{~kg}$.

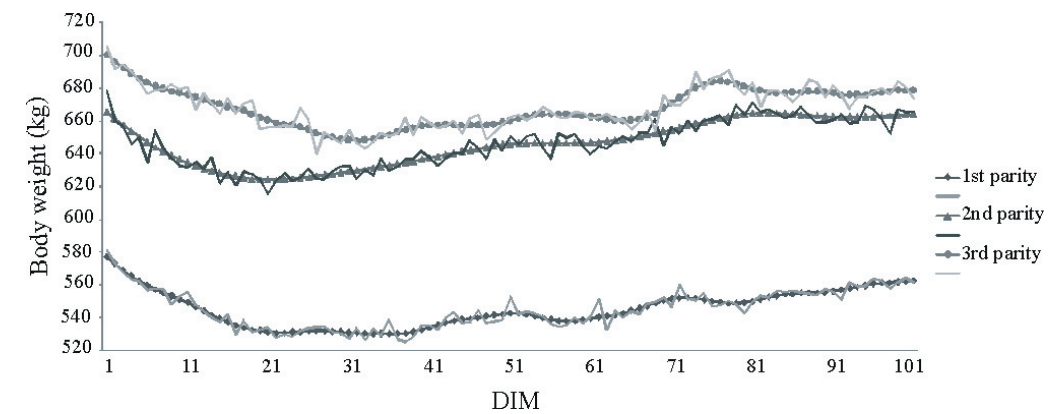

Figure 1 - Raw data and cubic splines smoothing of daily BW from calving to 100 DIM for first, second, third and subsequent parities.

\section{Discussion}

The difference between mean BW at calving and nadir BW ( $-51 \mathrm{~kg}$ of weight loss) was expected, due to the typical NEB in early lactation as described by Gross et al. (2011), who investigated BW loss and BCS associated with decreased dry matter intake (DMI) leading to mobilization of body reserves. Cumulative yields over the first 100 DIM of multiparous cows were greater $(\mathrm{P}<0.01)$ than those of primiparous cows, as it is well established that mature cows produce more milk than first-lactation ones (NRC, 2001).

Differences were found $(\mathrm{P}<0.05)$ in $\mathrm{BW}$ at calving and nadir BW according to the parity order. Cows of third and subsequent parities had higher $(\mathrm{P}<0.01) \mathrm{BW}$ at calving than second-parity and first-lactation cows. The highest BW at calving for cows of third lactation and over is in conformity with the NRC (2001), which states that primiparous cows should calve at 0.82 , second-parity at 0.92 , and cows in their third parity and over at their mature weight. As for nadir BW, the same trend as that of BW at calving was observed. These results are in agreement with data by Van Straten et al. (2008) in both characteristics.

The number of days from $\mathrm{BW}$ at calving to nadir $\mathrm{BW}$ and the absolute weight loss did not differ $(\mathrm{P}>0.05)$ between categories. These results disagreed with Van Straten et al. (2008), who concluded that NEB is proportional to the number of parities and animals in third parity and over require more DIM to reach the nadir BW. The results described here also disagree with Roche et al. (2007a), who showed that first- and second-parity cows lose less weight than older cows and the highest weight loss is seen in fifth-parity females $(46.3 \mathrm{~kg}$ and $45.4 \mathrm{~kg}$ vs. $52.9 \mathrm{~kg}$, 
$55.0 \mathrm{~kg}$ and $60.0 \mathrm{~kg}$, for first-, second-, third-, fourth-, and fifth-parity cows, respectively). Possible explanations for the absence of differences among the various parity classes in the present study is the modest difference in milk yield between primiparous and multiparous cows in this particular herd (only $3.8 \mathrm{~kg} \mathrm{day}^{-1}$ ), as well as the fact that this herd adopts one single diet (total mixed ration) for all groups of lactating cows.

Indeed, when weight variation was assessed in relative values, first-parity animals lost more weight $(\mathrm{P}<0.05)$ than second-parity cows, while cows in their third and subsequent parties showed intermediate values $(-7.3 \mathrm{~kg} /$ $100 \mathrm{~kg} \mathrm{BW}$ ). Alawneh et al. (2012), working with cows in several different parity orders grouped together in a pasturebased production system, obtained a slightly lower relative weight loss value. Their average weight loss between calving and the 28th day after calving was only $-4 \mathrm{~kg} / 100 \mathrm{~kg}$ of body weight. This difference may be explained by the more modest $\left(21 \mathrm{~L} \mathrm{day}^{-1}\right)$ production of these cows raised on pasture in New Zealand. Van Straten et al. (2008) found that relative $\mathrm{BW}$ change is proportional to the parity order $(-8.5,-10.6$ and $-11.1 \mathrm{~kg} / 100 \mathrm{~kg}$ for first, second, and subsequent parities, respectively), disagreeing with the results of this study. The probability of good reproduction (pregnant at $180 \mathrm{DIM}$ ) was greater for first parity than third and subsequent partities (44.0\% and 30.7\%, respectively) and the second parity had intermediate values (39.6\%). These results show that the primiparous cows evaluated in this study had better reproductive performance, even losing more body weight than the other categories.

In a trial conducted by Roche et al. (2007b), results suggested a positive correlation between higher losses in BCS with the height of the lactation curve and the fatcorrected milk yield (FCM), suggesting that cows with higher weight loss have greater milk production. The partial correlations between weight loss (both in absolute and relative values) and cumulative milk production were small or non-significant ( $\mathrm{P}>0.05$; Table 3 ), demonstrating that cows with higher weight loss did not necessarily produce more milk.

The probability of adequate reproduction at 180 DIM among the main risk factors is described. Firstparity animals had more chance $(\mathrm{P}<0.05)$ of a satisfactory reproduction than cows with three or more parities. The lower reproductive performance of mature cows was expected; however, the pregnancy ratio even in the younger cows was considered unsatisfactory, because more than half of the cows in this herd did not reach a 15-month maximum recommended calving interval (De Vries, 2006). For instance, Gilmore et al. (2011) found pregnancy rates of $71.4 \%$ at 100 days, well above the results of the present study. Santos et al. (2009) also observed higher conception rates on day 58 after artificial insemination on primiparous than multiparous cows $-37.5 \%$ vs. $29.7 \%$, respectively - confirming our finding that younger animals have better reproduction.

Reist et al. (2003) observed in their study that the average number of days to conception for dairy cows with satisfactory milk yield was 100.4 days $( \pm 47.4)$. De Vries and Veerkamp (2000) investigated the return of luteal activity in dairy cows and found that animals returned to ovarian activity on average at 29.7 DIM, ranging from 10 to 97 DIM. Considering a period of 100 days, animals returning to luteal activity near to 100 days would have their reproductive performance affected.

In the present study, the animals that had calved in the fall had more chances $(\mathrm{P}<0.01)$ of adequate reproduction (pregnant at 180 DIM) than those that had calved in summer and winter. Spring-calved animals showed intermediate chances of satisfactory reproduction. The reason for the poorest reproductive performance in winter-calved animals in this particular herd is the fact that cows calving in the winter are willing to get pregnant six months later (summer months), well recognized as the worst reproductive season, especially in warmer climates (Reist et al., 2003).

Roche (2006) stated that excessively low or excessively high weight and BCS at calving are associated with unsatisfactory reproductive response. Another interesting result was presented by Santos et al. (2009), who concluded that daily milk production did not impact pregnancy; however, a marked loss of BCS between calving and insemination had a negative impact on pregnancy rates. Cows that kept their BCS after calving showed a pregnancy rate of $41.6 \%$ against only $28.9 \%$ for those losing over 1 BCS point (scale of 1 to 5). Nevertheless, as shown by Drackley et al. (2014), BCS may be the same between animals with high and low BW, which can confuse the interpretation.

The same results were found in the present study, in which no differences $(\mathrm{P}>0.05)$ for likelihood of adequate reproduction among low, medium, and high cumulative milk yield groups were detected. Otherwise, cows with low and medium BW loss (below $60 \mathrm{~kg}$ of BW change) showed more $(\mathrm{P}<0.01)$ likelihood to adequate reproduction than cows with high BW loss (above $60 \mathrm{~kg}$ of BW). This finding is relevant because there is a myth in the dairy industry that high-producing cows will invariably have impaired reproduction performance. The absence of correlations between milk yield and reproduction was also pointed out by Santos et al. (2009). 
Butler (2000) explained that NEB is related to lower energy consumption capacity, and overweight cows have lower intake capacity than cows at optimal conditions. Also, the same author concluded that the higher NEB (in days and weight loss), the worse the reproductive performance in early lactation. This explains why heavier cows (supposedly fatter) showed poorer reproductive results in this study.

The curves of body weight change in the first 100 DIM are very similar to the findings of Nielsen et al. (2003), who investigated the body weight changes from week -5 to week 25 of lactation. Their results showed weight loss from week 0 to week 10, approximately, in accordance with the data obtained in this study. Assessing different genotypes and production systems, Vance et al. (2012) also demonstrated a similar body weight chart, corroborating the idea of NEB being a common physiological condition in early lactation.

\section{Conclusions}

Monitoring body weight at calving and in early lactation is a useful tool for management of dairy cows. Cows with better reproductive performance calve lighter and lose less weight after calving than cows with poorer reproductive performance. Nevertheless, high milk yield is not necessarily associated with poor reproductive efficiency.

\section{References}

Alawneh, J. I.; Stevenson, M. A.; Williamson, N. B.; LopezVilallobos, N. and Otley, T. 2012. The effect of liveweight change on reproductive performance in a seasonally calving, pasture fed dairy herd. Livestock Science 145:131-139.

Bobe, G.; Young, J. and Beitz, D. 2004. Invited review: Pathology, etiology, prevention, and treatment of fatty liver in dairy cows. Journal of Dairy Science 87:3105-3124.

Butler, W. R. 2000. Nutritional interactions with reproductive performance in dairy cattle. Animal Reproduction Science 6061:449-457.

Choumei, Y.; Kahi, A. K. and Hirooka, H. 2006. Fit of ood's function to weekly records of milk yield, total digestible nutrient intake and body weight changes in early lactation of multiparous Holstein cows in Japan. Livestock Science 104:156-164.

De Vries, A. 2006. Economic value of pregnancy in dairy cattle. Journal of Dairy Science 89:3876-3885.

De Vries, M. J. and Veerkamp, R. F. 2000. Energy balance of dairy cattle in relation to milk production variables and fertility. Journal of Dairy Science 83:62-69.

Drackley, J. K. 1999. Biology of dairy cows during the transition period: the final frontier? Journal of Dairy Science 82:2259-2273.

Drackley, J. K.; Wallace, R. L.; Graugnard, D.; Vasquez, J.; Richards, B. F. and Loor, J. J. 2014. Visceral adipose tissue mass in nonlactating dairy cows fed diets differing in energy density. Journal of Dairy Science 97:3420-3430.
Dubuc, J.; Duffield, T. F.; Leslie, K. E.; Walton, J. S. and LeBlanc, S. J. 2010. Risk factors for postpartum uterine diseases in dairy cows. Journal of Dairy Science 93:5764-5771.

Gilmore, H. S.; Young, F. J.; Patterson, D. C.; Wylie, A. R. G.; Law, R. A.; Kilpatrick, D. J.; Elliot, C. T. and Mayne, C. S. 2011. An evaluation of the effect of altering nutrition and nutritional strategies in early lactation on reproductive performance and estrous behavior of high-yielding Holstein-Friesian dairy cows. Journal of Dairy Science 94:3510-3526.

Gross, J.; Van Dorland, H. A.; Bruckmaier, R. M. and Schwarz, F. J. 2011. Performance and metabolic profile of dairy cows during a lactational and deliberately induced negative energy balance with subsequent realimentation. Journal of Dairy Science 94:1820-1830.

Jorritsma, R.; Wensing, T.; Kruip, T. A. M.; Vos, P. L. A. M. and Noordhuizen, J. P. T. M. 2003. Metabolic changes in early lactation and impaired reproductive performance in dairy cows. Veterinary Research 34:11-26.

Nielsen, H. M.; Friggens, N. C.; Løvendahl, P.; Jensen, J. and Ingvartsen, K. L. 2003. Influence of breed, parity, and stage of lactation on lactational performance and relationship between body fatness and live weight. Livestock Production Science 79:119-133.

NRC - National Research Council. 2001. Nutrient requirements of dairy cattle. 7th rev. ed. National Academy Press, Washington, DC

Reist, M.; Erdin, D. K.; Von-Euw, D.; Tschümperlin, K. M.; Leuenberger, H.; Hammon, H. M.; Morel, C.; Philipona, C.; Zbinden, Y.; Künzi, N. and Blum, J. W. 2003. Postpartum reproductive function: association with energy, metabolic and endocrine status in high yielding dairy cows. Theriogenology 59:1707-1723.

Roche, J. R. 2006. The effect of nutritional management of the dairy cow on reproductive efficiency. Animal Reproduction Science 96:282-296.

Roche, J. R.; Macdonald, K. A.; Burke, C. R.; Lee, J. M. and Berry, D. P. 2007a. Associations among body condition score, body weight, and reproductive performance in seasonal-calving dairy cattle. Journal of Dairy Science 90:376-391.

Roche, J. R.; Lee, J. M.; Macdonald, K. A. and Berry, D. P. 2007b. Relationships among body condition score, body weight, and milk production variables in pasture-based dairy cows. Journal of Dairy Science 90:3802-3815.

Santos, J. E. P; Rutigliano, H. M. and Sá Filho, M. F. 2009. Risk factors for resumption of postpartum estrous cycles and embryonic survival in lactating dairy cows. Animal Reproduction Science 110:207-221.

Santolaria, P.; López-Gatius, F.; Sánchez-Nadal, J. A. and Yániz, J. 2012. Relationships between body weight and milk yield during the early postpartum period and bull and technician and the reproductive performance of high producing dairy cows. Journal of Reproduction and Development 58:366-370.

Van Straten, M.; Shpygel, N. Y. and Friger, M. 2008. Analysis of daily body weight of high-producing dairy cows in the first one hundred twenty days of lactation and associations with ovarian inactivity. Journal of Dairy Science 91:3353-3362.

Vance, E. R.; Ferris, C. P.; Elliot, C. T.; Mcgettrick, S. A. and Kilpatrick, D. J. 2012. Food intake, milk production, and tissue changes of Holstein-Friesian and Jersey $\times$ Holstein-Friesian dairy cows within a medium-input grazing system and a high-input total confinement system. Journal of Dairy Science 95:1527-1544.

Wildman, E. E.; Jones, G. M.; Wagner, P. E.; Boman, R. L.; Troutt, H. F. and Lesch, T. N. 1982. A dairy cow body condition scoring system and its relationship to selected production characteristics. Journal of Dairy Science 65:495-501. 